\title{
Eunicida and Amphinomida polychaetes (Annelida) inhabiting dead coral fragments in the Chinchorro Bank Biosphere Reserve, Mexican Caribbean
}

\author{
Pablo Hernández-Alcántara ${ }^{1}$, Ismael Narciso Cruz-Pérez ${ }^{2} \&$ Vivianne Solís-Weiss ${ }^{3}$
}

1. Unidad Académica de Ecología y Biodiversidad Acuática, Instituto de Ciencias del Mar y Limnología, Universidad Nacional Autónoma de México. Circuito Exterior S/N, Cd. Universitaria, Ciudad de México, 04510, México, pabloh@cmarl.unam.mx

2. Facultad de Estudios Superiores Zaragoza, Universidad Nacional Autónoma de México. Batalla 5 de mayo S/N esquina Fuerte de Loreto, Colonia Ejército de Oriente, C.P. 09230, Ciudad de México, México, cupisma@yahoo.com.mx

3. Unidad Académica de Sistemas Arrecifales, Instituto de Ciencias del Mar y Limnología, Universidad Nacional Autónoma de México. Prol. Av. Niños Héroes s/n Puerto Morelos Quintana Roo, 77580, México, solisw@cmarl.unam.mx

\section{Received 08-VII-2018. Corrected 20-V-2019. Accepted 30-VI-2019.}

\begin{abstract}
Introduction: The polychaete fauna inhabiting Chinchorro Bank has been poorly studied and only 35 species have been previously reported. Objective: To examine the taxonomic composition of the Eunicida and Amphinomida associated to dead coral substrates from this coral reef atoll, a Biosphere Reserve located in the southern Mexican Caribbean. Methods: In April 2008, dead coral fragments of the genus Porites were manually collected by SCUBA diving at eight stations between 4-16.2 m depth. Results: A total of 714 individuals belonging to 17 genera and 48 species of the families Amphinomidae, Dorvilleidae, Eunicidae, Lumbrineridae, Oenonidae and Onuphidae were identified. Eunicidae was clearly the more diverse ( 29 species; $60.4 \%$ ) and abundant family (479 individuals; $67.1 \%$ ), while the Oenonidae and Onuphidae were represented by only one individual-species each. Thirty-eight species (79.2\%) were new records for Chinchorro Bank, of which 23 species $(47.9 \%$ ) were newly reported for the Western Caribbean ecoregion. Conclusions: The polychaete fauna recorded showed that the Chinchorro Bank reef is a species-rich habitat that deserves further study; the 48 species from six families identified were similar or even greater than the number of species reported from dead coral environments of other Caribbean Sea regions.
\end{abstract}

Key words: Polychaeta, species list, biodiversity, distribution, Mesoamerican Reef System.

Hernández-Alcántara, P., Cruz-Pérez, I. N., \& Solís-Weiss, V. (2019). Eunicida and Amphinomida polychaetes (Annelida) inhabiting dead coral fragments in the Chinchorro Bank Biosphere Reserve, Mexican Caribbean. Revista de Biología Tropical, 67(S5) Suplemento, S16-S38.

The Mesoamerican Barrier Reef System is the second largest barrier reef in the world, after the Great Barrier Reef in Australia (Carrillo, Johns, Smith, Lamkin, \& Largier, 2015). Stretching over $1000 \mathrm{~km}$, it goes from the tip of the Yucatan Peninsula, Mexico, down to Belize, Guatemala and Honduras. The
Chinchorro Bank Biosphere Reserve is part of this reef system (Instituto Nacional de Ecología [INE], 2000). It is located at the southeastern end of Mexico, approximately $39 \mathrm{~km}$ offshore from Mahahual, Quintana Roo (Fig. 1), and is one of the most important platform reefs of the Caribbean Sea (46 km long and $19 \mathrm{~km}$ in its 


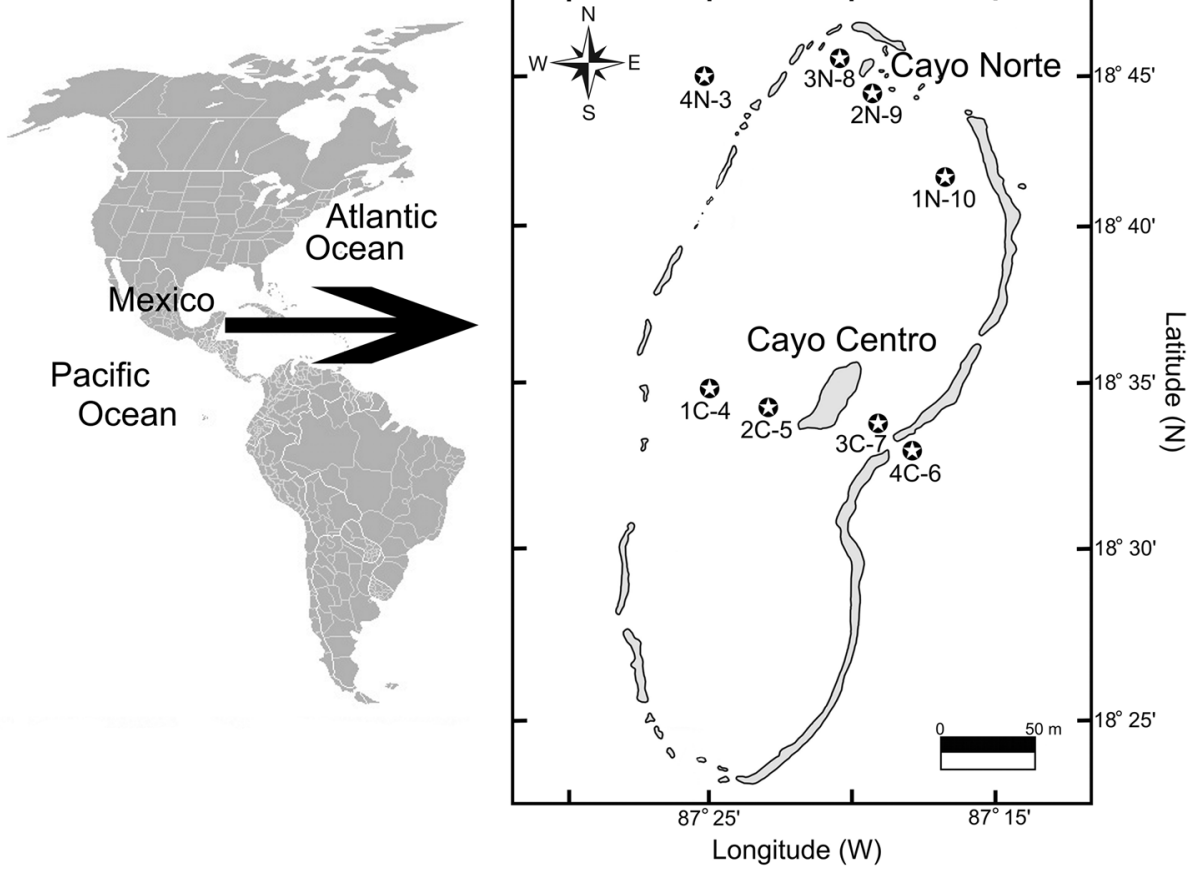

Fig. 1. Study area showing the sampling stations at Chinchorro Bank, Caribbean Sea.

widest part); it includes reef structures, a reef lagoon with an area of $550 \mathrm{~km}^{2}$, three cays and oceanic waters (De Jesús-Navarrete, 2003).

Coral reefs are among the most ecologically important marine ecosystems of the planet, due to their high biodiversity and productivity, complex biological relationships and intricate trophic structures, as well as high spatial heterogeneity associated with different habitats (Glynn, 1997; Fernández, Bone, \& Rodríguez, 2012; Bertness, Bruno, Silliman, \& Stachowicz, 2014). Corals are abundantly distributed in Chinchorro Bank, but extensive seagrass meadows and mangrove forests, which provide additional breeding habitats for many species, can also be found there (Ruiz-Abierno \& Armenteros, 2017).

The Caribbean Sea has been catalogued as one of the five worldwide "biodiversity hotspots" in marine environments (Roberts et al., 2002; Dean, 2012). More than 12000 species have been reported in this region, of which about $60 \%$ correspond to fishes, crustaceans and mollusks (Miloslavich et al., 2010). This implies that the other faunal groups are poorly known. Undoubtedly, this is the case for the annelid polychaetes, since only about $5 \%$ of the known marine species of the Caribbean Sea correspond to annelids (Costello et al., 2010; Dean, 2012), even though they are one of the main benthic groups worldwide. The presence of widespread seagrass meadows and mangrove forests, in addition to the dominating coral reefs, certainly provide breeding habitats for many species (Bertness et al., 2014; RuizAbierno \& Armenteros, 2017). Therefore, it is expected that the polychaete fauna inhabiting the Caribbean Sea is composed of many more species than the current records indicate (Dean, 2012).

In Chinchorro Bank, about 800 species of flora and fauna have been listed, of which about 280 are invertebrates, mainly corals, gastropoda, bivalvia and porifera (INE, 2000). In particular, the polychaetes are virtually unknown in this marine reserve, since there 
have been few studies on these worms and the existing reports were the result of occasional samplings in very restricted localities. From the Chinchorro Bank region, there were about 35 polychaete species, belonging to 10 families: Amphinomidae, Eunicidae, Euphrosinidae, Lumbrineridae, Maldanidae, Nereididae, Onuphidae, Sabellidae, Serpulidae and Terebellidae (Salazar-Vallejo, 1996, Carrera-Parra \& Salazar-Vallejo, 1998; Bastida-Zavala \& Salazar-Vallejo, 2000; Carrera-Parra, Fauchald, \& Gambi, 2011, among others).

Polychaetes are among the dominant invertebrates in dead coral fragments, followed by sipunculans, mollusks and crustaceans (Hutchings, 1983; Tribollet, Decherf, Hutchings, \& Peyrot-Clausade, 2002; Fernández et al., 2012). Usually, boring sponges, molluscs and sipunculans are the major bioeroders of corals causing the more importat loss of coraline substrates in mature boring communities (Hutchings, 1986, 2008). However, the polychaetes are important in the early stages of bioerosion in coralline substrates, since a succession of polychaetes colonizing those substrates facilitates subsequent recruitment by sponges, molluscs and sipunculans (Hutchings, 2008). In Chinchorro Bank, the high abundance and wide ocurrence at all the sampled stations of polychaetes of the family Eunicidae, could contribute to important modifications and degradation of the coralline skeletal structure due to their known bioeroder effects. Although few quantitative studies on the cryptic polychaetes have been carried out in the Caribbean Sea, they have shown that the eunicids are one of the most abundant and diverse families of polychaetes in dead coral environments (Ochoa-Rivera, Granados-Barba, \& Solís-Weiss, 2000; Fernández et al., 2012). On the other hand, in Chinchorro Bank, the Amphinomida group was only represented by the family Amphinomidae, which includes some large and coral reef-dwelling polychaetes, known commonly as "fireworms", Eurythoe complanata and Hermodice carunculata (Borda et al., 2015). Although the presence of amphinomids in the Mexican Caribbean is limited and only six species have been recorded, they are usually abundant in coral reefs, where they feed on anemones and coral polyps.

That is why the aim of the present study is to provide a more comprehensive database on the occurrence of the polychaete families, specifically focusing on the Eunicida and Amphinomida groups associated with dead coral fragments in the Chinchorro Bank Biosphere Reserve. These results may provide a useful tool to establish a baseline for the spatial characterization of this important invertebrate group and help in future analyses of the marine biodiversity of the Caribbean Sea.

\section{MATERIAL AND METHODS}

The biological material (dead coral) was collected in April 2008, at eight stations of the north and central regions of the Chinchorro Bank Biosphere Reserve (18 23' - 18 $47^{\circ}$ N; $87^{\circ} 14^{\prime}-87^{\circ} 27^{\prime} \mathrm{W}$ ) (Fig. 1). The samples were collected betweeen 4 and $16.2 \mathrm{~m}$ depth, and environmental data were also taken: salinity with a refractometer $( \pm 0.5 \mathrm{psu})$ and temperature $\left({ }^{\circ} \mathrm{C}\right)$ with a field mercury thermometer $\left( \pm 0.1^{\circ} \mathrm{C}\right)$ (Table 1$)$.

Coral fragments from the genus Porites were manually collected by SCUBA diving, which were selected because, among the stony fragmented corals, they showed the best porosity and potentially more opportunities for galleries (natural or digged), to shelter a higher number of individuals. About 5.6-12.4 kg were collected at each sampling site and the volume of fragments was measured in the field by water displacement. Samples were directly placed in a plastic bag and then fixed with 10 $\%$ formalin in seawater. In the laboratory, the rocks were washed with freshwater and carefully broken into small pieces to extract the specimens. The fragmented substrates were then washed through a $0.5 \mathrm{~mm}$ mesh sieve to retain the remaining organisms. Following fixation, all biological material was preserved in $70 \%$ ethanol.

Polychaetes were separated, classified into families and quantified. The polychaete cryptofauna in Chinchorro Bank was represented by 
TABLE 1

Location and depth of the sampling stations in Chinchorro Bank

\begin{tabular}{|c|c|c|c|c|}
\hline No. station & Locality & Latitude $\left({ }^{\circ} \mathrm{N}\right)$ & Longitude $\left({ }^{\circ} \mathrm{W}\right)$ & Depth (m) \\
\hline $1 \mathrm{~N}-10$ & La Caldera & $18^{\circ} 41^{\prime} 58.8^{\prime \prime}$ & $87^{\circ} 18^{\prime} 46^{\prime \prime}$ & 7 \\
\hline $2 \mathrm{~N}-9$ & Punta Norte & $18^{\circ} 45^{\prime} 25.6^{\prime \prime}$ & $87^{\circ} 19^{\prime} 51.1^{\prime \prime}$ & 8 \\
\hline $3 N-8$ & Cayo Norte & $18^{\circ} 45^{\prime} 59.9^{\prime \prime}$ & $87^{\circ} 19^{\prime} 52.7^{\prime \prime}$ & 10.15 \\
\hline $4 \mathrm{~N}-3$ & La Baliza & $18^{\circ} 45^{\prime} 29.7 \prime \prime$ & $87^{\circ} 25^{\prime} 07.5^{\prime \prime}$ & 16.2 \\
\hline $1 \mathrm{C}-4$ & Posterior region of La Baliza & $18^{\circ} 35^{\prime} 25.2^{\prime \prime}$ & $87^{\circ} 24^{\prime} 43.8^{\prime \prime}$ & 4 \\
\hline $2 \mathrm{C}-5$ & $\begin{array}{l}\text { Southwest of } \\
\text { Cayo Centro }\end{array}$ & $18^{\circ} 35^{\prime} 01.1 ”$ & $87^{\circ} 22^{\prime} 28.3^{\prime \prime}$ & 5 \\
\hline $3 \mathrm{C}-7$ & Posterior region of San Andres & $18^{\circ} 33^{\prime} 48.2^{\prime \prime}$ & $87^{\circ} 18^{\prime} 35.6^{\prime \prime}$ & 7 \\
\hline $4 C-6$ & San Andres & $18^{\circ} 33^{\prime} 13.8^{\prime \prime}$ & $87^{\circ} 17^{\prime} 57.3^{\prime \prime}$ & 9 \\
\hline
\end{tabular}

19 families (Table 2), and as has been observed in other Caribbean Sea regions (Ochoa-Rivera et al., 2000; Fernandez et al., 2012; Dean, 2016) the Syllidae was the most abundant family (563 individuals; $28 \%$ ), followed by the Eunicidae (479 individuals; $24 \%$ ), Nereididae (339 individuals; $17 \%$ ) and Lumbrineridae (187 individuals; $9 \%$ ). In the present study, we included the taxonomic revision of Eunicida and Amhinomida groups, which were so widely distributed in Chinchorro Bank that they represented $37 \%$ of the collected fauna; they were identified to species level. Of course, taxonomic revisions of the remaining families, yet under study, will be important in the future for a complete understanding of the occurrence and distribution of the polychaetes in Chinchorro Bank.

The Eunicida polychaetes were identified to species following the taxonomic keys of Gathof (1984a), Uebelacker (1984), Wolf (1984), Carrera-Parra \& Salazar-Vallejo (1997, 1998), Carrera-Parra (2006) and Molina-Acevedo \& Carrera-Parra (2017). For the Amphinomidae species, the keys and taxonomic descriptions published by Gathof (1984b), Salazar-Vallejo (1997), Yáñez-Rivera (2009), Liñero-Arana \& Díaz (2010) and Yáñez-Rivera \& Brown (2015) were used. The validity of the identified species names was verified with recent systematic reviews and with the World Polychaeta database (Read \& Fauchald, 2018). The identified specimens were deposited in the Colección Nacional de Anélidos
Poliquetos of the Instituto de Ciencias del Mar y Limnología (ICML), Universidad Nacional Autónoma de México (CNAP-ICML, UNAM: DFE.IN.061.0598).

\section{RESULTS}

A total of 714 individuals belonging to 17 genera and 48 species from the families Amphinomidae, Dorvilleidae, Eunicidae, Lumbrineridae, Oenonidae and Onuphidae were identified to species level. The Eunicidae was clearly the dominant family, representing 60.4 $\%$ (29 species) of the polychaetes identified to species level and $67.1 \%$ of all the organisms (479 ind.), followed by the Lumbrineridae ( 8 species; 187 ind.). The family Amphinomidae was represented by only 28 individuals, but four of the six species reported from the Mexican Caribbean were found in Chinchorro Bank, Eurythoe complanata being the most abundant and frequent amphinomid. The Oenonidae and Onuphidae were represented by only one individual (and therefore one species) each (Fig. 2).

The data obtained in this study indicate that, overall, 38 species (79.1\%) are newly reported for Chinchorro Bank, and that almost half $(47.9 \%)$ of the identified fauna (23 species) are new records for the Western Caribbean (Table 3). Eunice imogena was collected for the first time in the whole Caribbean Sea; previously, this eunicid had only been recorded from Hotspur Bank, Brazil (Fauchald, 1992a). 
TABLE 2

Families and number of species of polychaetes reported from some Caribbean Sea regions.

1) Archipelago Los Roques National Park, Venezuela (Fernández et al., 2012;

2) Caribbean coasts of Costa Rica (Dean, 2016); 3) Cozumel Island, Mexican Caribbean; 4) This study

\begin{tabular}{|c|c|c|c|c|}
\hline \multirow{2}{*}{ Family } & \multicolumn{4}{|c|}{ Collection site } \\
\hline & Northern Venezuela $^{1}$ & Caribbean Costa Rica ${ }^{2}$ & Mexican Caribbean ${ }^{3}$ & Chinchorro Bank ${ }^{4}$ \\
\hline Amphinomidae & Present & 3 & 3 & 4 \\
\hline Acoetidae & - & - & - & Present \\
\hline Capitellidae & Present & 1 & 3 & Present \\
\hline Chaetopteridae & - & 1 & - & - \\
\hline Chrysopetalidae & Present & 1 & - & Present \\
\hline Cirratulidae & - & 1 & - & Present \\
\hline Dorvilleidae & Present & - & 1 & 5 \\
\hline Eulepethidae & Present & - & - & - \\
\hline Eunicidae & 17 & 11 & 7 & 29 \\
\hline Flabelligeridae & - & 2 & - & Present \\
\hline Glyceridae & Present & 1 & 2 & - \\
\hline Hesionidae & - & - & 1 & - \\
\hline Lumbrineridae & Present & 1 & 2 & 8 \\
\hline Maldanidae & - & 1 & - & - \\
\hline Magelonidae & - & - & 1 & - \\
\hline Nereididae & Present & 6 & 5 & Present \\
\hline Oenonidae & - & 1 & - & 1 \\
\hline Onuphidae & Present & 1 & 1 & 1 \\
\hline Opheliidae & - & 1 & 2 & - \\
\hline Phyllodocidae & Present & - & 1 & Present \\
\hline Pilargidae & - & 1 & 1 & - \\
\hline Polynoidae & Present & 7 & 2 & Present \\
\hline Sabellariidae & - & 1 & - & - \\
\hline Sabellidae & Present & 6 & 1 & Present \\
\hline Serpulidae & Present & - & - & Present \\
\hline Sigalionidae & - & 1 & 1 & Present \\
\hline Spionidae & Present & 1 & 1 & - \\
\hline Syllidae & Present & 12 & 5 & Present \\
\hline Terebellidae & Present & 7 & 2 & Present \\
\hline Total & 17 & 22 & 19 & 19 \\
\hline
\end{tabular}

The eunicids Lysidice caribensis (190 ind.) and Nicidion obtusa (87 ind.), and the lumbrinerids Lumbrineris floridana (67 ind.) and Lumbrineris perkinsi (50 ind.) were the most abundant species (Table 3), which together with Eurythoe complanata, Eunice goodei, Eunice cf. rosaurae and Palola siciliensis were also the best represented species, occurring at least at $50 \%$ of the sampling stations. On the other hand, almost half of the identified species (22) was found only at one locality.
Salinity and temperature showed little variations among stations and their relationships with the distribution of the studied fauna was therefore not clear. However, depth appears to have a greater influence on the polychaete species presence, and although 20 species were located on a wide bathymetric range, almost half of the species $(47.9 \% ; 23$ species) occurred at less than $7 \mathrm{~m}$ depth, and only Eunice rubrivittata, Leodice antillensis, Marphysa fragilis, Scoletoma treadwelli and 


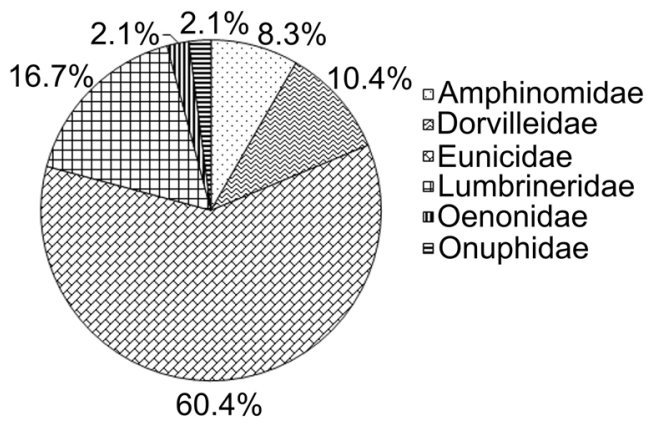

Fig. 2. Percentage of species per family of polychaetes in Chinhorro Bank.
Oenone cf. fulgida were found at deeper zones (between 8 and $16.2 \mathrm{~m}$ ).

\section{SYSTEMATIC ACCOUNT}

Family Amphinomidae Savigny

in Lamarck, 1818

Eurythoe complanata (Pallas, 1766)

Type locality: Caribbean Sea.

Material examined: 19 specimens

(CNAP-PO-49-003): Station 1N-10 (8 ind.),

TABLE 3

Taxonomic list of the species identified in the present study

\begin{tabular}{|c|c|c|}
\hline Family & Species & Abundance \\
\hline \multirow{4}{*}{$\begin{array}{l}\text { Amphinomidae Savigny } \\
\text { in Lamarck, } 1818\end{array}$} & Eurythoe complanata (Pallas, 1766) & 19 \\
\hline & Hermodice carunculata (Pallas, 1766) & 1 \\
\hline & * Linopherus cf. canariensis Langerhans, 1881 & 4 \\
\hline & Notopygos crinita Grube, 1855 & 4 \\
\hline \multirow[t]{5}{*}{ Dorvilleidae Chamberlin 1919} & Dorvillea largidentis Wolf, 1986 & 7 \\
\hline & ** Dorvillea rubra (Grube, 1856) & 3 \\
\hline & ** Dorvillea sociabilis (Webster, 1879) & 6 \\
\hline & ** Dorvillea vittata (Grube, 1856$)$ & 1 \\
\hline & ** Schistomeringos pectinata Perkins, 1979 & 1 \\
\hline \multirow[t]{21}{*}{ Eunicidae Berthold 1827} & ** Eunice barvicensis McIntosh, 1885 & 2 \\
\hline & ** Eunice brevis (Ehlers, 1887) & 3 \\
\hline & ** Eunice cf. collini Augener, 1906 & 7 \\
\hline & * Eunice donathi Carrera-Parra \& Salazar Vallejo, 1998 & 3 \\
\hline & * Eunice fucata Ehlers, 1887 & 21 \\
\hline & ** Eunice goodei Fauchald, 1992 & 25 \\
\hline & ** Eunice guanica (Treadwell, 1921) & 3 \\
\hline & * Eunice guildingi Bair, 1869 & 1 \\
\hline & *** Eunice imogena (Monro, 1924) & 4 \\
\hline & * Eunice lanai Carrera-Parra \& Salazar Vallejo, 1998 & 2 \\
\hline & ** Eunice polybranchia (Verrill, 1880) & 1 \\
\hline & ** Eunice cf. rosaurae Monro, 1939 & 11 \\
\hline & ** Eunice rubrivittata (Treadwell, 1921) & 2 \\
\hline & * Eunice sebastiani Nonato, 1965 & 3 \\
\hline & * Eunice unifrons (Verrill, 1900) & 2 \\
\hline & * Eunice websteri Fauchald, 1969 & 1 \\
\hline & * Leodice antennata (Savigny in Lamarck, 1818) & 2 \\
\hline & Leodice antillensis (Ehlers, 1887) & 4 \\
\hline & ** Leodice rubra (Grube, 1856) & 3 \\
\hline & * Lysidice adrianae Carrera-Parra, Fauchald \& Gambi, 2011 & 5 \\
\hline & Lysidice caribensis Carrera-Parra, Fauchald \& Gambi, 2011 & 190 \\
\hline
\end{tabular}


TABLE 3 (Continued)

\begin{tabular}{|c|c|c|}
\hline Family & Species & Abundance \\
\hline \multirow{16}{*}{ Lumbrineridae Schmarda 1861} & * Lysidice thalassicola Carrera-Parra, Fauchald \& Gambi, 2011 & 13 \\
\hline & * Lysidice unicornis (Grube, 1840) & 27 \\
\hline & Marphysa fragilis Treadwell, 1911 & 3 \\
\hline & * Nicidion angeli (Salazar-Vallejo \& Carrera- Parra, 1998) & 13 \\
\hline & * Nicidion mutilata (Webster, 1884) & 21 \\
\hline & Nicidion obtusa (Verrill, 1900) & 87 \\
\hline & * Palola siciliencis (Grube, 1840$)$ & 19 \\
\hline & ** Treadwellphysa cf. veracruzensis (De León-González \& Díaz-Castañeda, 2006) & 1 \\
\hline & ** Lumbrineris floridiana Ehlers, 1887 & 67 \\
\hline & Lumbrineris latreilli Audouin \& Milne-Edwards, 1834 & 10 \\
\hline & ** Lumbrineris nonatoi Ramos, 1976 & 16 \\
\hline & ** Lumbrineris paucidentata Treadwell, 1921 & 14 \\
\hline & ** Lumbrineris perkinsi Carrera-Parra, 2001 & 50 \\
\hline & ** Scoletoma elongata (Treadwell, 1931) & 25 \\
\hline & ** Scoletoma testudinum (Augener, 1922) & 4 \\
\hline & ** Scoletoma treadwelli (Harman, 1956) & 1 \\
\hline Oenonidae Kinberg 1865 & ** Oenone cf. fulgida (Savigny in Lamarck, 1818) & 1 \\
\hline Onuphidae Kinberg, 1865 & Mooreonuphis bidentata Rupit-Arteaga, Hernández-Alcántara \& Solís-Weiss, 2013 & 1 \\
\hline
\end{tabular}

(New records: $*=$ in Chinchorro Bank; $* *=$ in the Western Caribbean; $* * *=$ in the Caribbean Sea).

Station $2 \mathrm{~N}-9$ (2 ind.), Station $2 \mathrm{C}-5$ (4 ind.), Station 3C-7 (2 ind.), Station 4C-6 (3 ind.).

Habitat: Mainly in tropical and subtropical regions; sublittoral, down to $108 \mathrm{~m}$; on coral bottoms with Dendrophyllia ramea (Núñez, Brito, \& Ocaña, 1991); in shallow waters, mixed sediments, seagrass beds, in rocky shores (Salazar-Vallejo, 1997). Chinchorro Bank: in dead coral fragments, 5 to 9 m depth, 26.6 to $27.03{ }^{\circ} \mathrm{C}, 35.65$ to 35.79 psu.

Distribution: Amphi-Atlantic; Mediterranean Sea (Núñes et al., 1991); Mexican Caribbean (Salazar-Vallejo, 1997). Chinchorro Bank: La Caldera, Punta Norte, Southwest of Cayo Centro and San Andres.

Remarks: In small individuals, the internal region of the bifid neurosetae with small teeth, while in larger specimens, the bifid neurosetae are smooth and their distal region have a light honey tonality. The caruncle in small individuals is smooth with reniform eyes, while in larger individuals it is lightly rugose with rounded eyes.
Hermodice carunculata (Pallas, 1766)

Type locality: West Indies.

Material examined: A single specimen (CNAP-PO-49-008): Station 3C-7 (1 ind.).

Habitat: In tropical and subtropical shallow waters (Salazar-Vallejo, 1997; LiñeroArana \& Díaz, 2010). Associated to sessile organisms in rocky or mixed sediments bottoms (Salazar-Vallejo, 1997); on rocky bottoms and over coral colonies, mainly Diploria spp. and Meandrina spp. (Liñero-Arana \& Díaz, 2010). Common in low tide zones on all substrates; up to $108 \mathrm{~m}$ on coraline bottoms of Dendrophylia ramea, where juveniles are abundant; occasional in littoral pools (Núñez et al., 1991). Chinchorro Bank: in dead coral fragments, $7 \mathrm{~m}$ depth, $26.87{ }^{\circ} \mathrm{C}, 35.68 \mathrm{psu}$.

Distribution: Amphi-Atlantic; Mediterranean Sea; Caribbean Sea (Salazar-Vallejo, 1997; Liñero-Arana \& Díaz, 2010). Chinchorro Bank: Posterior region of San Andres. 
Remarks: The specimen collected has a thin black longitudinal line along its dorsum and its eyes are brown. Both characterisitcs were also noted by Salazar-Vallejo (1997) when he analyzed specimens from the Mexican Caribbean. According to that author, the black line on the dorsum could mean that it is a different species.

\section{Linopherus cf. canariensis Langerhans, 1881}

Type locality: Puerto de La Orotava, Tenerife.

Material examined: Four specimens (CNAP-PO-49-017): Station 2C-5 (2 ind.), Station 4C-6 (2 ind.).

Habitat: Shallow waters, associated with algae or in soft bottoms, with or without seagrasses. (Núñez et al., 1991; Salazar-Vallejo, 1997). Between branchs of Millepora alcicornis (Liñero-Arana \& Díaz, 2010). Chinchorro Bank: in dead coral fragments, 5 to $9 \mathrm{~m}$ depth, 26.6 to $26.57{ }^{\circ} \mathrm{C}, 35.69$ to 35.79 psu.

Distribution: Amphi-Atlantic: Canary Islands, Panama, Cuba, Mexico, Venezuela (Núñez et al., 1991; Salazar-Vallejo, 1997; Liñero-Arana \& Díaz, 2010). Chinchorro Bank: Southwest of Cayo Centro and San Andres.

Remarks: Linopherus canariensis was originally described with branchiae in chaetigers 3 to 7 (8 or 9) (Langerhans, 1881), however, several reports of other marine regions have showed that the branchial distribution could be very variable: in chaetigers 3-8 (San Martín, 1986), 3-7 (Peixoto \& Santos, 2015), 2-10 (16 or 20) (Salazar-Vallejo, 1997) or 2-20 (Liñero-Arana \& Díaz, 2010). Although specimens from Chinchorro Bank displayed a branchial distribution similar to that reported in the original description (chaetiger 2 to 6 with one to five filaments), in small individuals the caruncle is very small, its shape difficult to observe, and only in the largest organism the bifurcate, stout denticulate setae with a small basal spur and denticulate capillary chaetae were observed. It is evident that an examination of the type material is neccesary to clarify the taxonomic status of this species, justifying the "cf." adopted in this study.

Notopygos crinita Grube, 1855

Type locality: Saint Helena Island.

Material examined: Four specimens (CNAP-PO-49-016): Station 1N-10 (1 ind.), Station 2N-9 (1 ind.), Station 3C-7 (2 ind.).

Habitat: In rocky shores, but it swims up the water column to reproduce, in Padina $s p$. (Salazar-Vallejo, 1997); between branches of the alga Tricleocarpa cylindrica (Liñero-Arana \& Díaz, 2010). Chinchorro Bank: in dead coral fragments, 7 to $8 \mathrm{~m}$ depth, 26.76 to $27.03{ }^{\circ} \mathrm{C}$, 35.68 to $35.75 \mathrm{psu}$.

Distribution: Amphi-Atlantic: Caribbean Sea, Spain and France coasts (Salazar-Vallejo, 1997; Liñero-Arana \& Díaz, 2010). Chinchorro Bank: La Caldera, Punta Norte and Posterior region of San Andres.

Remarks: A black mark is visible along the dorsum in small specimens, and their eyes are black. According to Liñero-Arana \& Díaz (2010) the eyes in the adults are reddish. In small specimens, all neurochaetae are similar in size, but Salazar-Vallejo (1997) noted that some bifurcate neurochaetae are stouter. Liñero-Arana \& Díaz (2010) indicated that the dorsal cirri bear thin cirrophores, but SalazarVallejo (1997) observed that the cirrophores are stout, just as we observed in this study in Chinchorro Bank.

Family Dorvilleidae Chamberlin, 1919 Dorvillea largidentis Wolf, 1986

Type locality: Off Mobile Bay, Alabama, Gulf of Mexico.

Material examined: 7 specimens (CNAPPO-58-016): Station 2C-5 (7 ind.).

Habitat: At 22 to $642 \mathrm{~m}$ depth (Wolf, 1986); in coarse to fine sand, silty to fine sand (Wolf, 1984, 1986). Chinchorro Bank: in dead coral fragments, $5 \mathrm{~m}$ depth, $26.6{ }^{\circ} \mathrm{C}, 35.79 \mathrm{psu}$.

Distribution: off Florida and Alabama (Wolf, 1984); Puerto Rico; east coast of Florida (Wolf, 1986); Cuba (San Martín \& Major, 
1988); Grand Caribbean (Salazar-Vallejo \& Salazar, 2008). Chinchorro Bank: Southwest of Cayo Centro.

Remarks: According to Wolf (1986), in the specimens with 45 chaetigers, the antennae have 7 articles. However, in the specimens from Chinchorro Bank with 61 chaetigers, the antennae have 11 articles and the simple serrated chaetae in those individuals possess a very small distal tooth, not easy to detect, but not mentionned in the original diagnosis.

\section{Dorvillea rubra (Grube, 1856)}

Type locality: Caribbean Sea.

Material examined: Three specimens (CNAP-PO-58-013): Station 2C-5 (3 ind.).

Habitat: Crevices of rocks (Treadwell, 1921). Chinchorro Bank: in dead coral fragments, $5 \mathrm{~m}$ depth, $26.6{ }^{\circ} \mathrm{C}, 35.79 \mathrm{psu}$.

Distribution: Dry Tortugas, Florida; Tobago; St. Croix, Virgin Islands; Montego Bay, Jamaica (Treadwell, 1921); Cuba (Dean, 2012). Grand Caribbean (Salazar-Vallejo \& Salazar, 2008). Chinchorro Bank: Southwest of Cayo Centro.

Remarks: According to Treadwell (1921), the shape of supra-acicular neurochaetae is an important character to differentiate this species and the specimens he examined presented a well defined and long distal tooth. However, in our specimens, the distal tooth in the supra-acicular neurochaetae is small and not well defined.

\section{Dorvillea sociabilis (Webster, 1879)}

Type locality: Virginian coasts, Western Atlantic Ocean.

Material examined: Six specimens (CNAP-PO-58-017): Station 2C-5 (6 ind.).

Habitat: On shells (Webster, 1897). Intertidal to $160 \mathrm{~m}$ depth; on pilings and retaining walls; sand overlaid with shells, coarse sand (Wolf, 1984). Chinchorro Bank: in dead coral fragments, $5 \mathrm{~m}$ depth, $26.6{ }^{\circ} \mathrm{C}, 35.79 \mathrm{psu}$.

Distribution: Virginia to Florida; Northern Gulf of Mexico (Wolf, 1984); Cuba (Ibarzábal,
1986, 1997, 2006); Colombia; Guadeloupe; St. John (Dean, 2012); Mexican Caribbean (Ochoa-Rivera et al., 2000). Chinchorro Bank: Southwest off Cayo centro.

Remarks: Although one of the specimens we analysed did not have eyes, the palps are stout and smooth, the antennae articulate and smaller in size than the palps, all of which are morphologic characteristics corresponding to the species Dorvillea sociabilis. This species has been widely reported in the Gulf of Mexico and Caribbean Sea (Wolf, 1984; Ibarzábal 1986, 1997, 2006; Ochoa-Rivera et al., 2000; Dean, 2012), however, it is necessary to review its occurrence in tropical waters, since it was originally decribed from east coast of USA.

\section{Dorvillea vittata (Grube, 1856)}

Type locality: Puntarenas, Costa Rica.

Material examined: A single specimen (CNAP-PO-58-015): Station 2C-5 (1 ind.).

Habitat: In broken coral sand (Treadwell, 1921). Chinchorro Bank: in dead coral fragments, $5 \mathrm{~m}$ depth, $26.6{ }^{\circ} \mathrm{C}, 35.79$ psu.

Distribution: Dry Tortugas, Florida; Ely's Harbor, Bermuda (Treadwell, 1921). Chinchorro Bank: Southwest of Cayo Centro.

Remarks: The specimen analyzed was damaged and only an antenna shorter than the palps was preserved. Moreover, in the peristomium we could see a fold in each margin. Although in the original description no mention is made of this last characteristic, the other morphological characters agree well with the species description.

Schistomeringos pectinata Perkins, 1979

Type locality: Hutchinson Island, Florida.

Material examined: A single specimen (CNAP-PO-58-006): Station 2C-5 (1 ind.).

Habitat: At 7 to $106 \mathrm{~m}$ depth; medium to coarse calcareous sand (Perkins, 1979; Wolf, 1984). Chinchorro Bank: in dead coral fragments, 5 m depth, $26.6{ }^{\circ} \mathrm{C}, 35.79$ psu.

Distribution: Eastern Florida to Texas; Northern Gulf of Mexico (Perkins, 1979; Wolf, 
1984); Cuba (San Martín \& Major, 1988); Trinidad; Venezuela (Dean, 2012). Chinchorro Bank: Southwest of Cayo Centro.

Remarks: Although the specimen analyzed in this study lost its palps during the sampling, and most of its compound chaetae are broken in the anterior region of the body, in general the specimen agrees well with the description made by Perkins (1979).

Family Eunicidae Berthold, 1827

Eunice barvicensis McIntosh, 1885

Type locality: Bermuda.

Material examined: Two specimens (CNAP-PO-53-062): Station 2C-5 (1 ind.), Station 3C-7 (1 ind.).

Habitat: Intertidal (Fauchald, 1992a). Chinchorro Bank: in dead coral fragments, 5 to $7 \mathrm{~m}$ depth, $26.87^{\circ} \mathrm{C}, 35.68 \mathrm{psu}$.

Distribution: Bermuda (Fauchald, 1992a); Grand Caribbean (Salazar-Vallejo \& Salazar, 2008). Chinchorro Bank: Posterior region of San Andres and southwest of Cayo Centro.

Remarks: In specimens from Chinchorro Bank, the antennae are slightly shorter than those originally described (Fauchald, 1992a): A-I to the middle of peristomium, A-II to chaetiger 1; A-III to chaetiger 2 . In one of the organisms examined, the hooks are not totally black, but yellow at their base and black at the farther end.

Eunice brevis (Ehlers, 1887)

Type locality: Key West, Florida.

Material examined: Three specimens (CNAP-PO-53-072): Station 3C-7 (3 ind.).

Habitat: At 2 to $3 \mathrm{~m}$ depth (Fauchald, 1992a). Chinchorro Bank: in dead coral fragments, $7 \mathrm{~m}$ depth, $26.87^{\circ} \mathrm{C}, 35.68 \mathrm{psu}$.

Distribution: Florida (Fauchald, 1992a); Puerto Rico (Dean, 2012); Grand Caribbean (Salazar-Vallejo \& Salazar, 2008). Chinchorro Bank: Posterior region of San Andres.
Eunice cf. collini Augener, 1906

Type locality: Barbados.

Material examined: Seven specimens (CNAP-PO-53-073): Station 1N-10 (3 ind.), Station 2N-9 (2 ind.), Station 3C-7 (2 ind.).

Habitat: At $730 \mathrm{~m}$ depth (Fauchald, 1992a). Chinchorro Bank: at 7 to $8 \mathrm{~m}$ depth, in dead coral fragments, 26.76 to $27.63^{\circ} \mathrm{C}, 35.68$ to 35.75 psu.

Distribution: Off Barbados, Grenada (Fauchald, 1992a); Cuba; Martinique (Dean, 2012); Grand Caribbean (Salazar-Vallejo \& Salazar, 2008). Chinchorro Bank: La Caldera, Punta Norte and posterior region of San Andrés.

Remarks: The redescription of this species made by Fauchald (1992a) indicates that the subacicular hooks start at chaetiger 26, but in the specimens from Chinchorro Bank, they start at chaetiger 20. Also, the branchiae start two chaetigers before what is mentionned in the redescription (chaetiger 16). Finally, we could see a pair of eyes, while in the type material they are absent. These morphological differences made us classify them as Eunice cf. collini.

\section{Eunice donathi}

Carrera-Parra \& Salazar Vallejo, 1988

Type locality: Puerto Morelos, Mexican Caribbean.

Material examined: Three specimens (CNAP-PO-53-063): Station 1N-10 (3 ind.).

Habitat: Associated with the seagrass Thalassia (Carrera-Parra \& Salazar-Vallejo, 1998). Chinchorro Bank: in dead coral fragments, $7 \mathrm{~m}$ depth, $26.76{ }^{\circ} \mathrm{C}, 35.75 \mathrm{psu}$.

Distribution: Puerto Morelos, Quintana Roo, Mexican Caribbean (Carrera-Parra \& Salazar-Vallejo, 1997, 1998). Chinchorro Bank: La Caldera.

Remarks: In the analyzed specimens, branchiae have only one branchial filament, whereas in the original description two 
filaments are said to be present (Carrera-Parra \& Salazar-Vallejo, 1998).

\section{Eunice fucata Ehlers, 1887}

Type locality: Dry Tortugas, Florida.

Material examined: 21 specimens (CNAP-PO-53-037): Station 2N-9 (1 ind.), Station 2C-5 (19 ind.), Station 3C-7 (1 ind.).

Habitat: At 9-13 m depth. In soft bottoms (muds, sands, clays); 500-501 m depth (Fauchald, Granados-Barba, \& Solís-Weiss, 2009). Chinchorro Bank: in dead coral fragments, 5 to $8 \mathrm{~m}$ depth, 26.6 to $27.03{ }^{\circ} \mathrm{C}, 35.68$ to $35.76 \mathrm{psu}$.

Distribution: Dry Tortugas, Florida; Bahamas; Tobago; Montego Bay, Jamaica (Treadwell, 1921); Cuba (Ibarzábal, 2001, 2006; Ibarzábal, del Valle, Abreu, Espinosa, \& Cortés, 1999); Barbados; Puerto Rico (Dean, 2012); Caribbean Sea; tropical Atlantic Ocean (Carrera-Parra \& Salazar-Vallejo, 1997); Gulf of Mexico (Fauchald et al., 2009). Chinchorro Bank: Punta Norte, southwest of Cayo Centro and posterior region of San Andres.

Eunice goodei Fauchald, 1992

Type locality: Bermuda.

Material examined: 25 specimens (CNAP-PO-53-074): Station 1N-10 (17 ind.), Station $2 \mathrm{~N}-9$ (4 ind.), Station 2C-5 (3 ind.), Station 3C-7 (1 ind.).

Habitat: Chinchorro Bank: in dead coral fragments, 5 to $8 \mathrm{~m}$ depth, 26.6 to $27.03{ }^{\circ} \mathrm{C}$, 35.68 to $35.79 \mathrm{psu}$.

Distribution: Bermuda (Fauchald, 1992a). Antigua; Curaçao; Jamaica; Puerto Rico; Tobago (Dean, 2012). Chinchorro Bank: La Caldera, Punta Norte, southwest of Cayo Centro and posterior region of San Andres.

Remarks: In some of the specimens analyzed here, we could see faint articulations in the antennae, but Fauchald (1992a) describes them as smooth.

Eunice guanica (Treadwell, 1921)

Type locality: Key West, Florida.
Material examined: Three specimens (CNAP-PO-53-064): Station 1N-10 (3 ind.).

Habitat: Chinchorro Bank: in dead coral fragments, $7 \mathrm{~m}$ depth, $26.76^{\circ} \mathrm{C}, 35.75 \mathrm{psu}$.

Distribution: Puerto Rico; Key West, Florida; Montego Bay, Jamaica (Treadwell, 1921); Cuba (Ibarzábal, 1997, 2004); Colombia; Guadeloupe; Jamaica; Martinique; Panama; Puerto Rico (Dean, 2012). Chinchorro Bank: La Caldera.

Remarks: In this species the branchiae start at chaetiger 17 with up to two filaments and the hooks are present from chaetiger 36 (Fauchald, 1992a). However, in specimens from Chinchorro Bank we could see some minor differences: although the branchiae start at chaetiger 17 , they have only one filament and the subacicular hooks start at chaetiger 23 .

\section{Eunice guildingi Bair, 1869}

Type locality: St. Vincent, West Indies.

Material examined: A single specimen (CNAP-PO-53-049): Station 3C-7 (1 ind.).

Habitat: In shallow waters; in rocky or mixed sediments bottoms (Carrera-Parra \& Salazar-Vallejo, 1997). Chinchorro Bank: in dead coral fragments, $7 \mathrm{~m}$ depth, $26.87{ }^{\circ} \mathrm{C}$, 35.68 psu.

Distribution: St. Vincent, West Indies (Fauchald, 1992a); Cuba; Mexico; St. Vincent (Dean, 2012); Caribbean Sea (Carrera-Parra \& Salazar-Vallejo, 1997). Chinchorro Bank: Posterior region of San Andres.

Remarks: The presence of a very visible peristomial fold in the examined specimen is not mentionned in the species diagnosis (Fauchald, 1992a), but the rest of the morphological characteristics match those described for Eunice guildingi.

Eunice imogena (Monro, 1924)

Type locality: Hotspur Bank, Brazil.

Material examined: Four specimens (CNAP-PO-53-065): Station 1N-10 (2 ind.), Station 3C-7 (2 ind.). 
Habitat: In calcareous algae; $33 \mathrm{~m}$ depth (Luna, 1967). Chinchorro Bank: in dead coral fragments, $7 \mathrm{~m}$ depth, 26.76 to $26.87^{\circ} \mathrm{C}, 35.68$ to 35.75 psu.

Distribution: Hotspur Bank, Brazil (Fauchald, 1992a). Chinchorro Bank: La Caldera and posterior region of San Andres.

Remarks: The specimens agree well with the redescription made by Fauchald (1992a) based upon type material.

\section{Eunice lanai}

Carrera-Parra \& Salazar Vallejo, 1998

Type locality: Isla Mujeres, Mexican Caribbean.

Material examined: Two specimens (CNAP-PO-53-066): Station 3C-7 (2 ind.).

Habitat: On rocky bottoms; $74 \mathrm{~m}$ depth (Carrera-Parra \& Salazar-Vallejo, 1998). Chinchorro Bank: in dead coral fragments, $7 \mathrm{~m}$ depth, $26.87^{\circ} \mathrm{C}, 35.68 \mathrm{psu}$.

Distribution: Mujeres Island, Quintana Roo, Mexican Caribbean (Carrera-Parra \& Salazar-Vallejo, 1997, 1998). Chinchorro Bank: Posterior region of San Andres.

\section{Eunice polybranchia (Verrill, 1880)}

Type locality: Fish Hawk, Northwestern Atlantic Ocean.

Material examined: A single specimen (CNAP-PO-53-067): Station 3C-7 (1 ind.).

Habitat: Fine sand with some mud; 210 m depth (Fauchald, 1992a). Chinchorro Bank: in dead coral fragments, $7 \mathrm{~m}$ depth, $26.87^{\circ} \mathrm{C}$, 35.68 psu.

Distribution: Cuba (Ibarzábal, 2001); Grand Caribbean (Salazar-Vallejo \& Salazar, 2008). Chinchorro Bank: Posterior region of San Andres.

Remarks: Although the morphological characteristics of the examined specimen agreed well with the description of this species and that it has been previously recorded in the Caribbean Sea (Ibarzábal, 2001; SalazarVallejo \& Salazar, 2008), it is necessary to review its occurrence in tropical waters, since
E. polybranchia was originally described from the Nortwestern Atlantic.

Eunice cf. rosaurae Monro, 1939

Type locality: St. George, Grenada.

Material examined: 11 specimens (CNAP-PO-53-068): Station 1N-10 (3 ind.), Station $2 \mathrm{~N}-9$ (3 ind.), Station 2C-5 (2 ind.), Station 3C-7 (3 ind.).

Habitat: At 720-800 m depth (Fauchald, 1992a). Chinchorro Bank: in dead coral fragments, 5 to $8 \mathrm{~m}$ depth, 26.6 to $27.03{ }^{\circ} \mathrm{C}, 35.68$ to 35.79 psu.

Distribution: Off St. George, Grenada (Fauchald, 1992a). Grand Caribbean (SalazarVallejo \& Salazar, 2008). Chinchorro Bank: La Caldera, Punta Norte, southwest of Cayo Centro and posterior region of San Andres.

Remarks: In the examined specimens, the subaciular hooks start 10 chaetigers before and branchiae three chaetigers before those reported in the type material (Fauchald, 1992a). These differences could be associated to body size, since the type material has $152-170 \mathrm{~mm}$ length, while the individuals from Chinchorro Bank have up to $13 \mathrm{~mm}$ length. Therefore, they were left as Eunice cf. rosaurae until we have more information about its intra-specific variation.

\section{Eunice rubrivittata (Treadwell, 1921)}

Type locality: Bucco Bay, Tobago.

Material examined: Two specimens (CNAP-PO-53-055): Station 2N-9 (2 ind.).

Habitat: On rocks (Treadwell, 1921). Chinchorro Bank: in dead coral fragments, $8 \mathrm{~m}$ depth, $27.03{ }^{\circ} \mathrm{C}, 35.69 \mathrm{psu}$.

Distribution: Bucco Reef, Tobago (Treadwell, 1921; Fauchald, 1992a); Antigua; Guadeloupe; Tobago (Dean, 2012). Chinchorro Bank: Punta Norte.

Remarks: The presence or absence of eyes is not mentionned in the original description (Treadwell, 1921) or in the revision of type material (Fauchald, 1992a). However, in the specimens from Chinchorro Bank there is a pair of black eyes between antennae I and II. 
The other diagnostic characters agree well with the redescription made by Fauchald (1992a) based upon type material.

\section{Eunice sebastiani Nonato, 1965}

Type locality: Sao Sebastiao, Brazil.

Material examined: Three specimens (CNAP-PO-53-070): Station 1N-10 (1 ind.), Station 2N-9 (2 ind.).

Habitat: Intertidal; fine sand, muddy bottoms (Fauchald, 1992a); muddy bottoms, associated with sponges, or on dead floating wood (Carrera-Parra \& Salazar-Vallejo, 1997). Chinchorro Bank: in dead coral fragments, 8 to $7 \mathrm{~m}$ depth, 26.76 to $27.03{ }^{\circ} \mathrm{C}, 35.69$ to 35.75 psu.

Distribution: Sao Sebastiao, Brazil (Fauchald, 1992a); Perez Island, Yucatán; Quintana Roo coasts (Carrera-Parra \& Salazar-Vallejo, 1997). Chinchorro Bank: La Caldera and Punta Norte.

Remarks: As Fauchald (1992a) and Carrera-Parra and Salazar-Vallejo (1997) indicated, in smaller specimes some subacicular hooks are bidentate.

\section{Eunice unifrons (Verrill, 1900)}

\section{Type locality: Bermuda.}

Material examined: Two specimens (CNAP-PO-53-057): Station 1N-10 (2 ind.).

Habitat: Intertidal to $3 \mathrm{~m}$ depth (Fauchald, 1992a); in tubes formed of stones fastened together by organic matter (Treadwell, 1921); in coralline rocks (Carrera-Parra \& SalazarVallejo, 1997). Chinchorro Bank: in dead coral fragments, $7 \mathrm{~m}$ depth, $26.76{ }^{\circ} \mathrm{C}, 35.75 \mathrm{psu}$.

Distribution: Bermuda (Fauchald, 1992a); Dry Tortugas, Florida; Montego Bay, Jamaica (Treadwell, 1921); Cuba (Ibarzábal et al., 1999, 2001); Mexican Caribbean (CarreraParra \& Salazar-Vallejo, 1997); Gulf of Mexico (Fauchald et al., 2009). Chinchorro Bank: La Caldera.

\section{Eunice websteri Fauchald, 1969}

Type locality: Bermuda.
Material examined: A single specimen (CNAP-PO-53-011): Station 3C-7 (1 ind.).

Habitat: Intertidal to 22-43 m depth; coarse sand, silty fine sand (Gathof, 1984a). Chinchorro Bank: in dead coral fragments, $7 \mathrm{~m}$ depth, $26.87^{\circ} \mathrm{C}, 35.68$ psu.

Distribution: Bermuda (Fauchald, 1969, 1992a); Barbados; Colombia; Cuba; Martinique; Mexico; Panama; Puerto Rico; St. Lucia; Trinidad; Venezuela (Dean, 2012); North Carolina; Gulf of Mexico (Gathof, 1984a). Chinchorro Bank: Posterior region of San Andres.

\section{Leodice antennata}

(Savigny in Lamarck, 1818)

Type locality: Gulf of Suez.

Material examined: Two specimens (CNAP-PO-53-004): Station 2N-9 (1 ind.), Station 2C-5 (1 ind.).

Habitat: Intertidal to $275 \mathrm{~m}$ depth; on coral, shelly and rocky bottoms, coarse to medium sand, silty fine sand (Gathof, 1984a); mixed shallow bottoms (Carrera-Parra \& Salazar-Vallejo, 1997); at 1-60 m depth (Fauchald et al., 2009). Chinchorro Bank: in dead coral fragments, 5 to $8 \mathrm{~m}$ depth, 26.6 to $27.03{ }^{\circ} \mathrm{C}$, 35.69 to 35.79 psu.

Distribution: Gulf of Suez (Savigny in Lamarck, 1818); off Florida; Gulf of Mexico (Gathof, 1984a; Fauchald et al., 2009); Mexican Caribbean (Carrera-Parra \& Salazar-Vallejo, 1997); Colombia; Cuba; Mexico; Panama; Trinidad; Venezuela (Dean, 2012); possibly in the subtropical Atlantic, including the Mediterranean (Carrera-Parra \& Salazar-Vallejo, 1997). Chinchorro Bank: Punta Norte and southwest of Cayo Centro.

Remarks: The type material of $L$. antennata is lost (Fauchald, 1992a). Although this species was originally described from the Gulf of Suez (Savigny in Lamarck, 1818) and it is necessary to review its occurrence in the Tropical Atlantic, it has been widely reported from the Gulf of Mexico, Caribbean Sea and Central America (Gathof, 1984a; Carrera-Parra \& Salazar-Vallejo, 1997; Fauchald et al., 2009; Dean, 2012). 
Leodice antillensis (Ehlers, 1887)

Type locality: Blake, Southwestern Florida.

Material examined: Four specimens (CNAP-PO-53-038): Station 2N-9 (4 ind.).

Habitat: At $185 \mathrm{~m}$ depth (Fauchald (1992a); 49 m depth (Fauchald et al., 2009); mixed hard bottoms; at 70-200 m depth (Carrera-Parra \& Salazar-Vallejo, 1998). Chinchorro Bank: in dead coral fragments, $8 \mathrm{~m}$ depth, $27.03{ }^{\circ} \mathrm{C}, 35.69 \mathrm{psu}$.

Distribution: Florida to Mexican Caribbean (Carrera-Parra \& Salazar-Vallejo, 1997); Gulf of Mexico (Fauchald et al., 2009). Chinchorro Bank: Punta Norte.

\section{Leodice rubra (Grube, 1856)}

Type locality: St. Thomas, West Florida.

Material examined: Three specimens (CNAP-PO-53-069): Station 1N-10 (1 ind.), Station 3N-8 (1 ind.), Station 2C-5 (1 ind.).

Habitat: In coral rocks (Treadwell, 1921); in soft bottoms; at 1-58 $\mathrm{m}$ depth (Fauchald et al., 2009); in calcareous algae; at 16-75 m depth (Luna, 1967). Chinchorro Bank: in dead coral fragments, 5 to $10.15 \mathrm{~m}$ depth, 26.6 to $26.76^{\circ} \mathrm{C}, 35.74$ to $35.79 \mathrm{psu}$.

Distribution: St. Thomas, West Indies (Fauchald, 1992a); Bermuda; Dry Tortuga, Florida; Tobago; Cuba; North Carolina (Treadwell, 1921); Aruba; Barbados; Puerto Rico; Colombia; Panama; Venezuela (Dean, 2012); Gulf of Mexico (Fauchald et al., 2009). Chinchorro Bank: La Caldera, Cayo Norte and southwest of Cayo Centro.

\section{Lysidice adrianae}

Carrera-Parra, Fauchald \& Gambi, 2011

Type locality: Off Ria Lagartos, Southern Gulf of Mexico.

Material examined: Five specimens (CNAP-PO-53-071): Station 1N-10 (3 ind.), Station 2N-9 (1 ind.), Station 2C-5 (1 ind.).

Habitat: In coralline rocks; in coral rubble; at 1-3 m depth (Carrera-Parra, Fauchald \&
Gambi, 2011). Chinchorro Bank: in dead coral fragments, at 5 to $8 \mathrm{~m}$ depth, 26.6 to $26.76{ }^{\circ} \mathrm{C}$, 35.69 to 35.79 psu.

Distribution: Gulf of Mexico: Ria Lagartos, Yucatan; Campeche; Mexican Caribbean (Carrera-Parra et al., 2011). Chinchorro Bank: La Caldera, Punta Norte and southwest of Cayo Centro.

\section{Lysidice caribensis}

Carrera-Parra, Fauchald \& Gambi, 2011

Type locality: Punta Nizuc, Cancun, Mexican Caribbean

Material examined: 190 specimens (CNAP-PO-53-076): Station 1N-10 (88 ind.), Station $2 \mathrm{~N}-9$ (49 ind.), Station $4 \mathrm{~N}-3$ (3 ind.), Station 2C-5 (27 ind.), Station 3C-7 (23 ind.).

Habitat: In coralline rocks; coral rubble; seagrassbeds of Thalassia testudinum and Syringodium filiforme; at 1.5-4 m depth (Carrera-Parra et al., 2011). Chinchorro Bank: in dead coral fragments, 5 to $16.2 \mathrm{~m}$ depth, 26.15 to $27.03{ }^{\circ} \mathrm{C}, 35.69$ to $35.79 \mathrm{psu}$.

Distribution: Quintana Roo, Mexican Caribbean (Carrera-Parra et al., 2011). Chinchorro Bank: La Caldera, Punta Norte, La Baliza, southwest of Cayo Centro and posterior region of San Andres.

Remarks: In small specimens, the second peristomial ring cannot be distinguished, and in some individuals the subacicular hooks and falcigers are worn out, so the distal teeth are indistinguishable. Other morphological characteristics agree well with the original description.

\section{Lysidice thalassicola}

Carrera-Parra, Fauchald \& Gambi, 2011

Type locality: Puerto Morelos, Mexican Caribbean.

Material examined: 13 specimens (CNAP-PO-53-077): Station $1 \mathrm{~N}-10$ (8 ind.), Station 3N-8 (1 ind.), Station 3C-7 (4 ind.).

Habitat: Borer of sheaths of Thalassia testudinum; at $3 \mathrm{~m}$ depth (Carrera-Parra et al., 2011). Chinchorro Bank: in dead coral 
fragments, 7 to $10.15 \mathrm{~m}$ depth, 26.35 to 26.87 ${ }^{\circ} \mathrm{C}, 35.68$ to $35.75 \mathrm{psu}$.

Distribution: Puerto Morelos, Quintana Roo, Mexican Caribbean; Belize (Carrera-Parra et al., 2011). Chinchorro Bank: La Caldera, Cayo Norte and posterior region of San Andres.

Remarks: In some specimens the eyes are reniform rather than rounded as indicated the original description (Carrera-Parra et al., 2011).

Lysidice unicornis (Grube, 1840)

Type locality: Meditterranean Sea.

Material examined: 27 specimens (CNAP-PO-53-008): Station 1N-10 (5 ind.), Station 2C-5 (17 ind.), Station 3C-7 (5 ind.).

Habitat: Associated with Posidonia oceanica (Gambi, 2000) and Thalassia testudinum; coarse sediments (Gambi, van Tussenbroek, \& Brearley, 2003); coarse to fine sands; silty fine sands; 15-106 m depth (Gathof, 1984a). Chinchorro Bank: in dead coral fragments, 5 to 8 $\mathrm{m}$ depth, 26.6 to $26.87{ }^{\circ} \mathrm{C}, 35.79$ to $35.68 \mathrm{psu}$.

Distribution: Mexican Caribbean; Mediterranean Sea (Gambi et al., 2003); Bermuda; Gulf of Mexico (Gathof, 1984a). Circumtropical (Salazar-Vallejo \& Carrera-Parra, 1997). Chinchorro Bank: La Caldera, southwest of Cayo Centro and posterior region of San Andres.

Remarks: The subacicular hooks start on chaetigers 10-11, and in general, the examined individuals agree well with the species original description and the observations of SalazarVallejo \& Carrera-Parra (1997).

\section{Marphysa fragilis Treadwell, 1911}

Type locality: Dry Tortugas, Florida.

Material examined: Three specimens (CNAP-PO-53-079): Station 2N-9 (3 ind.).

Habitat: At 2-60 m depth; in coralline rocks; in crevices of soft rocks; in dead Strombus gigas shells; in Thalassia testudinum and Syringodium filiforme seagrassbeds (MolinaAcevedo \& Carrera-Parra, 2017). Chinchorro Bank: in dead coral fragments, $8 \mathrm{~m}$ depth, $27.03{ }^{\circ} \mathrm{C}, 35.69 \mathrm{psu}$.
Distribution: Dry Tortugas, Florida (Treadwell, 1911); Northeast Dominican Republic; Antigua; East St. Vincent and the Grenadines; Mexican Caribbean (Molina-Acevedo \& Carrera-Parra, 2017); Gulf of Mexico (Fauchald et al., 2009). Chinchorro Bank: Punta Norte.

\section{Nicidion angeli}

(Salazar-Vallejo \& Carrera- Parra, 1998)

Type locality: Xamach, Quintana Roo, Mexican Caribbean.

Material examined: 13 specimens (CNAP-PO-53-078): Station $1 \mathrm{~N}-10$ (8 ind.), Station 2C-5 (1 ind.), Station 3C-7 (4 ind.).

Habitat: At 3-5 m depth; in coralline rocks; in algae; in sediments with Thalassia testudinum (Molina-Acevedo \& Carrera-Parra, 2017). Chinchorro Bank: in dead coral fragments, 5 to $7 \mathrm{~m}$ depth, 26.6 to $26.87{ }^{\circ} \mathrm{C}, 35.68$ to $35.79 \mathrm{psu}$.

Distribution: Quintana Roo, Mexican Caribbean (Molina-Acevedo \& Carrera-Parra, 2017). Chinchorro Bank: La Caldera, southwest of Cayo Centro and posterior region of San Andres and.

\section{Nicidion mutilata (Webster, 1884)}

Type locality: Bermuda.

Material examined: 21 specimens (CNAP-PO-53-025): Station 1N-10 (1 ind.), Station 2C-5 (13 ind.), Station 3C-7 (7 ind.).

Habitat: Associated with Phragmatopoma caudata, on coral reefs (De León-González \& Díaz-Castañeda, 2006). Chinchorro Bank: in dead coral fragments, 5 to $7 \mathrm{~m}$ depth, 26.6 to $26.87^{\circ} \mathrm{C}, 35.68$ to $35.79 \mathrm{psu}$.

Distribution: Bermuda (Fauchald, 1992a). Amphiamerican in tropical waters. Quintana Roo, Mexican Caribbean; Veracruz, Gulf of Mexico; Mexican Pacific: Revillagigedo Islands; Jalisco; Nayarit (De León-González \& Díaz-Castañeda, 2006). Chinchorro Bank: La Caldera, southwest of Cayo Centro and posterior region of San Andres. 
Remarks: In the specimens examined, minor variations were noticed with respect to the redescription of Fauchald (1992a), since the branchiae have up to six filaments, while in the type material four filaments are present at their maximum development.

\section{Nicidion obtusa (Verrill, 1900)}

\section{Type locality: Bermuda.}

Material examined: 87 specimens (CNAP-PO-53-094): Station 1N-10 (33 ind.), Station 4N-3 (2 ind), Station 2C-5 (38 ind.), Station 3C-7 (14 ind.).

Habitat: At 1-40 m depth; in rocks, coralline rocks, sands, algae, Thalassia testudinum and Syringodium filiforme seagrassbeds, in Millepora sp., in bivalves (Molina-Acevedo \& Carrera-Parra, 2017). Chinchorro Bank: in dead coral fragments, 5 to $16.2 \mathrm{~m}$ depth, 26.6 to $26.87^{\circ} \mathrm{C}, 35.68$ to $35.77 \mathrm{psu}$.

Distribution: Widely distributed in the Mexican Caribbean, including Chinchorro Bank; Contoy Island, Cancún, Puerto Morelos Quintana Roo; Chinchorro Bank; Southern Gulf of Mexico; Jamaica; St. Vincent and the Grenadines; Barbuda; Venezuela; off Guatemala; Gulf of Honduras (Molina-Acevedo \& Carrera-Parra, 2017). Chinchorro Bank: La Caldera, La Baliza, southwest of Cayo Centro and posterior region of San Andres.

\section{Palola siciliencis (Grube, 1840)}

Type locality: Mediterranean Sea.

Material examined: 19 specimens (CNAP-PO-53-028): Station 1N-10 (6 ind.), Station $2 \mathrm{~N}-9$ (6 ind.), Station 2C-5 (5 ind.), Station 3C-7 (2 ind.).

Habitat: Shallow waters in warm regions; on hard bottoms (Fauchald, 1992b). Chinchorro Bank: in dead coral fragments, 5 to 8 m depth, 26.6 to $27.03{ }^{\circ} \mathrm{C}, 35.68$ to 35.79 psu.

Distribution: Palermo, Sicily; Trieste, Italy (Fauchald, 1992b). Belize; Barbados; Colombia; Cuba; Curaçao; Panama; Puerto Rico; Tobago; Venezuela (Dean, 2012); Circumtropical (Salazar-Vallejo \& Carrera-Parra
1997). Chinchorro Bank: La Caldera, Punta Norte, southwest of Cayo Centro and posterior region of San Andres.

Remarks: The specimens examined in this study have some minor differences with respect to Fauchald (1992b) and Salazar-Vallejo \& Carrera-Parra (1997) redescriptions: in some examined specimens the antennae are slightly longer and the aciculae are not totally black but slightly yellow; also the eyes of some organisms are reniform.

\section{Treadwellphysa cf. veracruzensis}

(De León-González \& Díaz-Castañeda, 2006)

Type locality: Veracruz, Southwestern Gulf of Mexico.

Material examined: A single specimen (CNAP-PO-53-080): Station 3C-7 (1 ind.).

Habitat: In rocks; at 1-3 m depth (De León-González \& Díaz-Castañeda, 2006). Chinchorro Bank: in dead coral fragments, $7 \mathrm{~m}$ depth, $26.87^{\circ} \mathrm{C}, 35.68$ psu.

Distribution: Southtern Gulf of Mexico: Veracruz; Campeche; Yucatán (De León-González \& Díaz-Castañeda, 2006; Molina-Acevedo \& Carera-Parra, 2017). Chinchorro Bank: Posterior region of San Andres.

Remarks: The examined individual was identified as close to this species because it is incomplete. Therefore, we cannot confirm the presence of anodont pectinate chaetae in posterior chaetigers; other morphological characteristics agree with the redescription made by Molina-Acevedo \& Carrera-Parra (2017), which was based on type material.

Family Lumbrineridae Schmarda, 1861 Lumbrineris floridana Ehlers, 1887

Type locality: Key West, Florida.

Material examined: 67 specimens (CNAP-PO-54-050): Station 1N-10 (10 ind.), Station 2N-9 (29 ind.), Station 2C-5 (20 ind.), Station 3C-7 (3 ind.), Station 4C-6 (5 ind.).

Habitat: Coral rubble; rocks; in algae; at $0.5-71 \mathrm{~m}$ depth (Carrera-Parra, 2006). 
Chinchorro Bank: in dead coral fragments, 5 to $9 \mathrm{~m}$ depth, 26.6 to $27.03{ }^{\circ} \mathrm{C}, 35.68$ to 35.79 psu.

Distribution: Dry Tortugas, Florida; Bermuda (Treadwell, 1921); Key West, Florida; Cuba; Venezuela; off Barbuda; British Virgin Islands; Veracruz, Yucatan, Quintana Roo, Mexico (Carrera-Parra, 2006); Colombia; Curaçao; Puerto Rico; Venezuela (Dean, 2012). Chinchorro Bank: La Caldera, Punta Norte, southwest of Cayo Centro, posterior region of San Andres and San Andres.

Remarks: In the specimens examined the distribution of the composite multidentate hooded hooks is variable, since they start at chaetigers 1 or 2 and end at chaetigers 7-12.

\section{Lumbrineris latreilli \\ Audouin \& Milne-Edwards, 1834}

Type locality: Iles Chaussey, France.

Material examined: 10 specimens (CNAP-PO-54-004): Station 3N-8 (2 ind.), Station 2C-5 (5 ind.), Station 3C-7 (3 ind.).

Habitat: Intertidal to $2360 \mathrm{~m}$; coarse to very fine sand, gravel, shell fragments, mud rock, algae (Uebelacker, 1984). Chinchorro Bank: in dead coral fragments, 5 to $10.15 \mathrm{~m}$ depth, 26.6 to $26.87{ }^{\circ} \mathrm{C}, 35.68$ to 35.79 psu.

Distribution: Northeastern Atlantic; Mediterranean Sea; Northern Gulf of Mexico (Uebelacker, 1984); Cuba (Ibarzábal, 1986); questionably cosmopolitan (Carrera-Parra, 2006). Chinchorro Bank: Cayo Norte, southwest of Cayo Centro and posterior region of San Andres.

Remarks: This species was originally described from France coasts and although it has been recorded from Northern Gulf of Mexico and Cuba, its occurrence in tropical waters should be carefully reviewed, noting especially that the distribution of the hooded hooks along the body is highly variable: the last composite multidentate hooks are found in chaetigers 18-24 and the first simple multidentate hooks appear at chaetigers 19-25, the other characteristics of specimens from Chinchorro Bank correspond with the morphology described for this species.

\section{Lumbrineris nonatoi Ramos, 1976}

Type locality: Mediterranean Sea.

Material examined: 16 specimens (CNAP-PO-54-045): Station 1N-10 (14 ind.), Station 1C-4 (1 ind.), Station 2C-5 (1 ind.).

Habitat: At 15-56 m depth (Carrera-Parra, 2006). Chinchorro Bank: in dead coral fragments, 4 to $7 \mathrm{~m}$ depth, 26.6 to $26.41{ }^{\circ} \mathrm{C}, 35.79$ to $35.76 \mathrm{psu}$.

Distribution: Mediterranean Sea; Gulf of Mexico: Texas; Florida; Tamaulipas; Veracruz; Tabasco; Campeche (Carrera-Parra, 2006). Chinchorro Bank: La Caldera, posterior region of La Baliza and southwest of Cayo Centro.

Remarks: The examined specimens show minor differences with the redescription of this species made by Carrera-Parra (2006), since the pre- and postchaetal lobes on posterior chaetigers are similar in length, and although in maxilla II, four teeth are present, apparently one tooth could be a maxilla pulp, since its root is not observed (Carrera-Parra pers. comm.).

\section{Lumbrineris paucidentata Treadwell, 1921}

Type locality: Dry Tortugas, Florida.

Material examined: 14 specimens (CNAP-PO-54-057): Station 2C-5 (14 ind.).

Habitat: Chinchorro Bank: in dead coral fragments, $5 \mathrm{~m}$ depth, $26.6^{\circ} \mathrm{C}, 35.79 \mathrm{psu}$.

Distribution: Dry Tortugas, Florida (Treadwell, 1921); Bahamas; Quintana Roo, Mexican Caribbean (Carrera-Parra, 2006); Cuba (Suárez \& Fraga 1978). Chinchorro Bank: Southwest of Cayo Centro.

Remarks: Carrera-Parra (2006) indicates that dorsal limbate chaetae are present in chaetigers 1 to 55; however, in specimens from Chinchorro Bank, they appear only in chaetigers 1 to 22-26. Other morphological characteristics agree well with the redescription based on type material made by Carrera-Parra (2006).

Lumbrineris perkinsi Carrera-Parra, 2001

Type locality: Veracruz, Southwestern Gulf of Mexico. 
Material examined: 50 specimens (CNAP-PO-54-051): Station 1N-10 (2 ind.), Station 2N-9 (3 ind.), Station 1C-4 (12 ind.), Station 2C-5 (24 ind.), Station 3C-7 (3 ind.), Station 4C-6 (6 ind.).

Habitat: Intertidal to $81 \mathrm{~m}$ depth; in coralline rocks; sponges; mangrove roots (CarreraParra, 2001, 2006). Chinchorro Bank: in dead coral fragments, 4 to $8 \mathrm{~m}$ depth, 26.6 to 27.03 ${ }^{\circ} \mathrm{C}, 35.79$ to $35.68 \mathrm{psu}$.

Distribution: Gulf of Mexico: Tamaulipas; Veracruz; Campeche; Yucatán; Mexican Caribbean: Quintana Roo; Cuba; Dominican Republic; British Virgin Islands; Panama; Brazil (Carrera-Parra, 2001, 2006). Chinchorro Bank: La Caldera, Punta Norte, posterior region of La Baliza, southwest of Cayo Centro, posterior region of San Andres and San Andres.

Remarks: Although in some specimens from Chinchorro Bank we can only observe four teeth in maxilla II, in general, the examined specimens agree with the original description (Carrera-Parra, 2001).

Scoletoma elongata (Treadwell, 1931)

Type locality: Grand Island, Louisiana.

Material examined: 25 specimens (CNAP-PO-54-039): Station 1N-10 (8 ind.), Station 2N-9 (6 ind.), Station 1C-4 (2 ind.), Station 2C-5 (6 ind.), Station 4C-6 (3 ind.).

Habitat: Chinchorro Bank: in dead coral fragments, 4 to $9 \mathrm{~m}$ depth, 26.6 to $27.03{ }^{\circ} \mathrm{C}$, 35.75 to 35.79 psu.

Distribution: Grand Island, Louisiana (Treadwell, 1931); Gulf of Mexico (CarreraParra, 2001). Chinchorro Bank: La Caldera, Punta Norte, posterior region of La Baliza, southwest of Cayo Centro and San Andres.

Remarks: The specimens from Chinchorro Bank agree well with the characteristics of this species, although some individuals have a ventral black line along their body, a feature not previously signaled. In his study, CarreraParra (2001) indicates that the holotype of this species is damaged, even lacking its maxillary apparatus, which makes it necessary to review in detail the diagnostic characteristics of Scoletoma elongata.

Scoletoma testudinum (Augener, 1922)

Type locality: Dry Tortugas, Florida.

Material examined: Four specimens (CNAP-PO-54-056): Station 2N-9 (3 ind.), Station 2C-5 (1 ind.).

Habitat: Chinchorro Bank: in dead coral fragments, 5 to $8 \mathrm{~m}$ depth, 26.6 to $27.03{ }^{\circ} \mathrm{C}$, 35.69 to 35.79 psu.

Distribution: Dry Tortugas, Florida (Perkins, 1979); Southern Veracruz and Quintana Roo, Grand Caribbean (Carrera-Parra, 2001). Chinchorro Bank: Punta Norte and southwest of Cayo Centro.

\section{Scoletoma treadwelli (Harman, 1956)}

Type locality: Puerto Real, Puerto Rico.

Material examined: A single specimen (CNAP-PO-54-047): Station 4N-3 (1 ind.).

Habitat: In sands, muds and clays (Fauchald et al., 2009). Chinchorro Bank: in dead coral fragments, $16.2 \mathrm{~m}$ depth, $26.15^{\circ} \mathrm{C}$, 35.77 psu.

Distribution: Puerto Rico; Florida; Cuba; Guadeloupe; Veracruz, Mexican Caribbean (Carrera-Parra, 2001). Chinchorro Bank: La Baliza.

Family Oenonidae Kinberg, 1865

Oenone cf. fulgida (Savigny in Lamarck, 1818).

Type locality: Red Sea.

Material examined: A single specimen (CNAP-PO-56-011): Station 3N-8 (1 ind.).

Habitat: Intertidal to $177 \mathrm{~m}$ depth; coral reefs and sandy sediments (Uebelacker, 1984). Chinchorro Bank: in dead coral fragments, $10.15 \mathrm{~m}$ depth, $26.35^{\circ} \mathrm{C}, 35.74$ psu.

Distribution: Circumtropical; North Carolina; Gulf of Mexico; temperate regions of Argentina (Uebelacker, 1984). Colombia; Cuba; Curaçao; Jamaica; Tobago; West Indies; 
Panama (Dean, 2012). Chinchorro Bank: Cayo Norte.

Remarks: In the literature, great differences in several morphological characteristics of Oenone fulgida have been reported, such as the first appearance of the acicular chaetae (between chaetigers 14 to 70) (Uebelacker, 1984), which have raised the possibility of separation into different species (Fauchald, 1970). Accordingly, the specimen examined was left as Oenone cf. fulgida until more detailed examination of the diagnostic characters of the species can be carried out.

Family Onuphidae Kinberg, 1865

Mooreonuphis bidentata Rupit-Arteaga, Hernández-Alcántara \& Solís-Weiss, 2013.

Type locality: Puerto Morelos, Mexican Caribbean.

Material examined: A single specimen (CNAP-POP-52-001): Station 2C-5 (1 ind.).

Habitat: On dead coral rocks; at 2.2-9 m depth (Rupit-Arteaga, Hernández-Alcántara \& Solís-Weiss, 2013). Chinchorro Bank: in dead coral fragments, $5 \mathrm{~m}$ depth, $26.6{ }^{\circ} \mathrm{C}, 35.79 \mathrm{psu}$.

Distribution: Mexican Caribbean (RupitArteaga et al., 2013). Chinchorro Bank: Southwest of Cayo Centro.

\section{DISCUSSION}

According to the marine biogeography classification system suggested by Spalding et al. (2007), the Grand Caribbean is included in the Northwestern Atlantic Province and the coasts of Mexico are part of the Western Caribbean ecoregion, one of the regions where a lower number of polychaete species (417, including records of the present study) has been reported. On the contrary, the highest species richness has been found in the Greater Antilles (652 species), specifically around Cuba (533 species) (Dean, 2012), but we assume that this is, at least in part, since more intense polychaete surveys have been done more frequently. According to Dean (2012), since Pallas published the first records of polychaetes in the Caribbean Sea in 1766: Eurythoe complanata (as Aphrodita complanata), Hermodice carunculata (as Aphrodita carunculata) and Spirobranchus giganteus (as Serpula gigantea), the existing reports of polychaetes for the area have reached around 1200 species from 59 families.

In the Mexican Caribbean, 306 polychaete species have been registered, of which only 73 species (including the 38 new records provided in this study) were reported from Chinchorro Bank (23.9\%), making it clear that a lot of work is still necessary to evaluate the diversity of this region. Although relatively little is known about the distribution patterns of polychaetes in reefs and coralline environments, and a systematic approach needs to be carried out to bring the species data to a comparable level with other coralline regions, the present study indicated that the dead coral rubble collected at 4 to $16.2 \mathrm{~m}$ depth along the Chinchorro Bank reef is a species-rich habitat that deserves further study. The 19 families found here were similar in number to those polychaete families reported from coral reef environments in other Caribbean regions: 17 families in Northern Venezuela, 19 in Cozumel Island and 22 in the Caribbean coasts of Costa Rica (Table 2). Although only the Eunicida and Amphinomida groups were examined to species level, their observed data also showed that the 48 species from six families found in Chinchorro Bank could be similar or even greater than the 42 species from 19 families recorded in dead coral substrates from Cozumel Island, Mexican Caribbean (Ochoa-Rivera et al., 2000), or the 68 polychaete species from 22 families reported from intertidal coralline rocks and some subtidal localities of the Caribbean coasts of Costa Rica (Dean, 2016).

Although in the present study only the Eunicida and Amphinomida were examined, the great abundance and number of species of eunicids in coral environments was evident in this area, since it is one of the most important families of polychaetes in Chinchorro Bank and, up to now, the taxon with the largest number of species recorded. Eunicids are one 
of the more diverse and abundant families of polychaetes found in dead coral fragments in the Caribbean Sea. The exception is the Costa Rican coasts where rocks and rootmats of seagrasses were also sampled and the syllids were the most diverse with 12 species. The present study also showed that the 29 species of eunicids found in Chinchorro Bank were clearly larger than the 17 species recorded in northern Venezuela (Fernández et al., 2012), the 11 species reported in Costa Rica (Dean, 2016) or the 7 species collected in Cozumel Island (Ochoa-Rivera et al., 2000). Eunicids live in well developed borings, which they dig with their complex and well developed jaws; acid secretions may also occur, but this has not been verified (Hutchings, 2008). Although their densities change with the habitat and local peculiarities, large eunicids, often reaching many centimeters in length, are usually most abundant as the boring communities mature (Hutchings, 2008). This could be evidence of the high level of fragmentation of the corals and maturity of the polychaete assemblages populating these environments in Chinchorro Bank.

On the contrary, although the amphinomids reach their highest diversity in shallow tropical and subtropical environments, playing an important ecological role in coralline and rocky habitats (Kudenov, 1995), in Chinhorro Bank they were not as abundant as expected. Some species, such as Hermodice carunculata, which is a common resident of coral reefs and littoral zones of the Caribbean Sea, has been considered a major and voracious predator of both soft and hard corals, and prey on zoanthids, anemones, gorgonids, hydrocorals, scleractinians and octocorals, among others (De Assis, Dias, \& Christoffersen, 2017). However, the occurrence of this species, but also of all other amphinomid species, on dead coral environments, clearly decreases in Chinchorro Bank and other Caribbean regions (OchoaRivera et al., 2000; Fernández et al., 2012; Dean, 2016). So, the few abundant species identified (four), compared to the 20 species reported from the Caribbean Sea (Dean, 2012), showed that their populations do not reach a significant development in the examined dead coral environments.

This is the first sistematic revision of the polychaete species inhabiting the Chinchorro Bank Biosphere Reserve, and the taxonomic information presented here contributes to the understanding of the occurrence of the polychaete fauna in the Western Caribbean ecoregion, where the relatively limited number of studies and low sampling effort do not emphasize adequately the importance of the marine biodiversity in this invertebrate group.

Ethical statement: authors declare that they all agree with this publication and made significant contributions; that there is no conflict of interest of any kind; and that we followed all pertinent ethical and legal procedures and requirements. All financial sources are fully and clearly stated in the acknowledgements section. A signed document has been filed in the journal archives.

\section{ACKNOWLEDGMENTS}

We would like to thank María del Carmen García, Director of the "Chinchorro Bank Biosphere Reserve, Quintana Roo" who allowed us to use all the facilities of the Chinchorro field Station, including transportation to and from the atoll. Our deepest gratitude goes to Admiral Francisco M. Sáynez (then Naval Secretary of Mexico), who gave us all the needed logistic support in the field for this project. Sarita Frontana, Efrain Chávez and Guy Doyhemboure are especially acknowledged for their sustained help in the field, together with all the other participants in that expedition.

\section{RESUMEN}

\section{Poliquetos de Eunicida y Amphinomida (Annelida) que habitan fragmentos de coral muertos en la Reserva de Biosfera del Banco Chinchorro, Caribe Mexicano}

Introducción: La fauna de poliquetos que habita en el Banco Chinchorro ha sido poco estudiada y solo se han registrado alrededor de 35 especies. Objetivo: Examinar la composición taxonómica de los Amphinomida y Eunicida 
asociados a sustratos de coral muerto en este atolón coralino, una Reserva de la Biosfera ubicada al sur del Caribe mexicano. Métodos: En abril de 2008 se recolectaron manualmente fragmentos de coral muerto por medio de buceo SCUBA en ocho estaciones entre 4-16.2 $\mathrm{m}$ de profundidad. Resultados: Se identificaron 714 individuos pertenecientes a 17 géneros y 48 especies de las familias Amphinomidae, Dorvilleidae, Eunicidae, Lumbrineridae, Oenonidae y Onuphidae. Eunicidae fue claramente la familia más diversa (29 especies, $60.4 \%$ ) y abundante (479 individuos, 67.1\%); en cambio Oenonidae y Onuphidae estuvieron representadas por solo un individuo de una especie. Treinta y ocho especies $(79.2 \%)$ fueron nuevos registros para el Banco Chinchorro, de las cuales 23 especies $(47.9 \%)$ fueron registradas por primera vez en la ecorregión del Caribe Occidental. Conclusiones: La fauna de poliquetos registrada mostró que el arrecife del Banco Chinchorro es un hábitat rico en especies que merece estudios adicionales; las 48 especies de seis familias identificadas fueron similares o incluso superiores al número de especies registradas en ambientes de coral muerto de otras regiones del Mar Caribe.

Palabras clave: Polychaeta, lista de especies, biodiversidad, distribución, Sistema Arrecifal.

\section{REFERENCES}

Bastida-Zabala, J. R., \& Salazar-Vallejo, S. I. (2000). Serpúlidos (Polychaeta: Serpulidae) del Caribe noroccidental Hydroides y Serpula. Revista de Biología Tropical, 48(4), 841-858.

Bertness, M. D., Bruno, J. F., Silliman, B. R., \& Stachowicz, J. J. (Eds.) (2014). Marine community ecology and conservation. Sunderlan, Massachusetts, USA: Sinauer Associates Inc.

Borda, E., Yáñez-Rivera, B., Ochoa, G. M., Kudenov, D., Sanchez-Ortiz, C., Schukze, A., ... Rouse, G. W. (2015). Revamping Amphinomidae (Annelida: Amphinomida), with the inclusión of Notopygos. Zoologica Scripta, 41, 307-325.

Carrera-Parra, L. F. (2001). Lumbrineridae (Annelida: Polychaeta) from the Grand Caribbean region with the description of six new species. Journal of the Marine Biological Association of the United Kingdom, 81, 599-621.

Carrera-Parra, L. F. (2006). Revision of Lumbrineris de Blainville, 1828 (Polychaeta: Lumbrineridae). Zootaxa, 1336, 1-64.

Carrera-Parra, L. F., \& Salazar-Vallejo, S. I. (1997). Eunícidos (Polychaeta) del Caribe mexicano con claves para las especies del Gran Caribe: Eunice. Revista de Biologia Tropical, 45, 1499-1521.
Carrera-Parra, L. F., \& Salazar-Vallejo, S. I. (1998). A new genus and 12 new species of Eunicidae (Polychaeta) from the Caribbean Sea. Journal of the Marine Biological Association of the United Kingdom, 78, 145-182.

Carrera-Parra, L. F., Fauchald, K., \& Gambi, M. C. (2011). Revision of the taxonomic status of Lysidice (Polychaeta, Eunicidae) in the Western Caribbean Sea with observation on species reproductive features and habitat preference. Italian Journal of Zoology, 78(S1), 27-40.

Carrillo, L., Johns, E. M., Smith, R. H., Lamkin, J. T., \& Largier, J. L. (2015). Pathways and hydrography in the Mesoamerican Barrier Reef System. Part 1: Circulation. Continental Shelf Research, 109, 164-176.

Costello, M. J., Coll, M., Danovaro, R., Halpin, P., Ojaveer, H., \& Miloslavich, P. (2010). A census of marine biodiversity knowledge, resources, and future challenges. Plos ONE, 5(8) e12110, 1-15.

Dean, H. K. (2012). A literature review of the Polychaeta of the Caribbean Sea. Zootaxa, 3596, 1-86.

Dean, H. K. (2016). Some intertidal and shallow water polychaetes of the Caribbean coast of Costa Rica. Revista de Biología Tropical, 65, 127-152.

De Assis, J. E., Dias, T. L. P., \& Christoffersen, M. L. (2017). New record for South America of an attack of the fireworm Hermodice carunculata (Polychaeta, Amphinomidae) on a colony of Palythoa caribaeorum (Sphenopidae, Hexacorallia), in Maracajaú, Rio Grande do Norte, Brazil. Pan-American Journal of Aquatic Science, 12(3), 259-262.

De Jesús-Navarrete, A. J. (2003). Physical characterization of the reef lagoon at Banco Chinchorro, Mexico: an overview. Bulletin of Marine Science, 73, 5-14.

De León-Gonzáles, J. A., \& Díaz-Castañeda, V. (2006). Eunicidae (Annelida: Polychaeta) associated with Phragmathopoma caudate Morch, 1863 and some coral reef from Veracruz, Gulf of Mexico. Scientia Marina, 70S3, 91-99.

Fauchald, K. (1969). A Revision of Six Species of the Flavus-Bidentatus Group of Eunice (Eunicidea: polychaeta). Smithsonia Contributions to Zoology, $6,1-15$.

Fauchald, K. (1970). Polychaetous Annelids of the Families Eunicide, Lumbrineridae, Iphitimide, Arabellidae, Lysaretidae and Dorvilleidae from western Mexico. Allan Hancock Monographs in Marine Biology, 5, 1-335.

Fauchald, K. (1992a). A review of the genus Eunice (Polychaeta: Eunicidae) based upon type material. Smithsonian Contributions to Zoology, 523, 1-422. 
Fauchald, K. (1992b). Review of the types of Palola (Eunicidae: Polychaeta). Journal of Natural History, $26,1177-1225$.

Fauchald, K., Granados-Barba, A., \& Solís-Weiss, V. (2009). Polychaeta (Annelida) of the Gulf of Mexico. In D. L. Felder \& D. K. Camp (Eds.). Gulf of Mexico. Origin, Waters, and Biota. Volume 1, Biodiversity. (pp. 751-788). Texas, USA: Texas A\&M University Press.

Fernández, P. V., Bone, D., \& Rodríguez, C. (2012). Cryptofaunal polychaetes from oceanic and continental reefs in Venezuela. Bulletin of Marine Science, 88(2), 339-352.

Gambi, M. C. (2000). Polychaete borers of Posidonia oceanica (L.) Delile scales: distribution patterns and ecological role. Biologia Marina Mediterranea, 7, 215-219.

Gambi, M. C., van Tussenbroek, B. I., \& Brearley, A. (2003). Mesofaunal borers in seagrasses: world-wide occurrence and a new record of boring polychaetes in the Mexican Caribbean. Aquatic Botany, 76, 65-77.

Gathof, J. M. (1984a). Chapter 40. Eunicidae. In J. M. Uebelacker \& P. G. Johnson (Eds.). Taxonomic Guide to the Polychaetes of the Northern Gulf of Mexico. Final Report to the Minerals Management Service, contract 14-12-001-29091 (pp. 40.1-40.31). Mobile, Alabama, USA: Barry A. Vittor and Associates. Inc.

Gathof, J. M. (1984b). Chapter 37. Amphinomidae. In J. M. Uebelacker \& P. G. Johnson (Eds.). Taxonomic Guide to the Polychaetes of the Northern Gulf of Mexico. Final Report to the Minerals Management Service, contract 14-12-001-29091 (pp. 37.1-37.12). Mobile, Alabama, USA: Barry A. Vittor and Associates. Inc.

Glynn, P. W. (1997). Bioerosion and coral reefs growth: A dynamic balance. In C. Birkeland (Ed.). Life and death of coral reefs (pp. 8-95). Nueva York, USA: Chapman-Hall.

Hutchings, P. A. (1983). Cryptofaunal communities of coral reefs. In D. J. Barnes (Ed.). Perspectives on coral reefs (pp. 200-208). Australia: Australian Institute of Marine Sciences.

Hutchings, P. A. (1986). Biological destruction of coral reefs - A review. Coral Reefs, 4, 239-252.

Hutchings, P. A. (2008). Role of polychaetes in bioerosion of coral substrates. In M. Wisshak \& L. Tapanila (Eds.). Current developments in bioerosion (pp. 249264). Berlin, Germany: Springer-Verlag.

Ibarzábal, D. R. (1986). Lista de especies de poliquetos bentónicos cubanos. Reporte de Investigación del Instituto de Oceanología, 45, 1-17.
Ibarzábal, D.R. (1997). Estructura ecológica de una comunidad caribeña de poliquetos arrecifales. Avicennia, 6/7, 85-102.

Ibarzábal, D. R. (2001). Eunícidos (Annelida: Polychaeta) del Archipiélago Jardines de la Reina, plataforma suroriental de Cuba. Avicennia, 14, 75-83.

Ibarzábal, D. R. (2004). Nuevos registros de poliquetos para el Golfo de Batabanó y el Archipiélago de los Canarreos, SW de Cuba. Avicennia, 17, 41-48.

Ibarzábal, D. R. (2006). Poliquetos del Archipiélago de Sabana-Camagüey, ecoregión norcentral de Cuba. Cocuyo, 16, 11-14.

Ibarzábal, D. R., del Valle, R., Abreu, M., Espinosa, J., \& Cortés, R. (1999). Listado preliminar de los poliquetos, moluscos y equinodermos marinos del Archipiélago de los Jardines de la Reina. Cocuyo, 9, 3-6.

Instituto Nacional de Ecología. (2000). Programa de manejo Reserva de la Biosfera Banco Chinchorro. México: Instituto de Ecología, SEMARNAP.

Kudenov, J. D. (1995). Family Amphinomidae Lamarck, 1818. In J. A. Blake, B. Hilbig \& P. H. Scott (Eds.). Taxonomic atlas of the benthic fauna of the Santa Maria Basin and Western Santa Barbara Channel, Vol. 5: The Annelida. Part 2. Polychaeta: Phyllodocida (Syllidae and scale-bearing families), Amphinomida, and Eunicida (pp. 207-215). San Diego, California, USA: Santa Barbara Museum.

Liñero-Arana, I., \& Díaz, O. (2010). Amphinomidae y Euphrosinidae (Annelida: Polychaeta) de la costa nororiental de Venezuela. Latin American Journal of Aquatic Research, 38, 107-120.

Luna, A. (1967). Shelf off Alagoas and Sergipe (Northeastern Brazil): 4. Polychaetous annelids (Preliminary report). Trabalhos Oceanograficos Universidade Federal de Peernambuco, Recife, 9/11, 193-222.

Miloslavich, P., Díaz, J. M., Klein, E., Alvarado, J. J., Díaz, C., Gobin, J., ... Ortiz, M. (2010). Marine biodiversity in the Caribbean: regional estimates and distribution patterns. PloS ONE, 5(8) e11916, 1-25.

Molina-Acevedo, I. C., \& Carrera-Parra, L. F. (2017). Revision of Marphysa de Quatrefages, 1865 and some species of Nicidion Kinberg, 1865 with the erection of a new genus (Polychaeta: Eunicidae) from the Grand Caribbean. Zootaxa, 4241, 1-62.

Núñez, J., Brito, M. C., \& Ocaña, O. (1991). Anélidos poliquetos de Canarias: Familia Amphinomidae. Cahiers de Biologie Marine, 32, 469-476.

Ochoa-Rivera, V., Granados-Barba, A., \& Solís-Weiss, V. (2000). The polychaete cryptofauna from Cozumel Island, Mexican Caribbean. Bulletin of Marine Science, 67, 137-146. 
Pallas, P. S. (1766). Miscellanea zoologica. Quibus novae imprimis atque obscurae animalium species describuntur et observationibus iconibusque illustrantur. Petrum van Cleef. Hagí Comitum.

Peixoto, A. J. M., \& Santos, C. S. G. (2015). First record of Linopherus cf. canariensis (Polychaeta: Amphinomidae) from Rio de Janeiro, Brazil. Marine Biodiversity Records, 8, e152.

Perkins, T. H. (1979). Lumbrineridae, Arabellidae, and Dorvilleidae (Polychaeta), principally from Florida, withy descriptions of six new species. Proceedings of the Biological Society of Washington, 92, 415-465.

Read, G., \& Fauchald, K. (Ed.) (2018). World Polychaeta database. Eunicida. Accessed through: World Register of Marine Species. Retrieved from http://www. marinespecies.org/aphia.php? $\mathrm{p}=$ taxdetails $\& \mathrm{id}=895$

Roberts, M. R., McClean, C. J., Veron, J. E. N., Hawkins, J. P., Allen, G. R., McAllister, D. E., ... Werner, T. B. (2002). Marine biodiversity hotspots and conservation priorities for tropical reefs. Science, 295, 1280-1284

Rupit-Arteaga, S. K., Hernández-Alcántara, P., \& SolísWeiss, V. (2012). Description of Mooreonuphis bidentata a new species of Onuphidae (Annelida: Polychaeta) from the Mexican Caribbean with remarks on the distribution of the genus. Journal of the Marine Biological Association of the United Kingdom, 93(4), 981-990.

Ruiz-Abierno, A., \& Armenteros, M. (2017). Coral reef habitats strongly influence the diversity of macroand meiobenthos in the Caribbean. Marine Biodiversity, 47, 101-111.

Salazar-Vallejo, S. I. (1996). Filodócidos (Polychaeta: Phyllodocidae) del Caribe Mexicano con claves para identificar las especies del Gran Caribe. Revista de Biologia Tropical, 44, 107-122.

Salazar-Vallejo, S. I. (1997). Anfinómidos y eufrosínidos (Polychaeta) del Caribe Mexicano con claves para las especies reconocidas del Gran Caribe. Revista de Biologia Tropical, 44, 379-390.

Salazar-Vallejo, S. I., \& Carrera-Parra, L. F. (1997). Eunícidos (Polychaeta) del Caribe mexicano con claves para las especies del Gran Caribe: Fauchaldius, Lysidice, Marphysa, Nematonereis y Palola. Revista de Biologia Tropical, 45, 1481-1498.

Salazar-Vallejo, S. I., \& Salazar, P. (2008). Catálogo de autoridad taxonómica de las especies de poliquetos (Annelida: Polychaeta) del Gran Caribe. México: Base de datos SNIB-CONABIO EE004.

San Martín, G. (1986). Anélidos poliquetos procedentes de la I Expedición Cubano-Española a la isla de la Juventud y archipiélago de los Canarreos, 2. Familias Chrysopetalidae y Amphinomidae. Revista de Investigaciones marinas, 7, 7-30.
San Martín, G., \& Major, S. (1988). Anélidos poliquetos procedentes de la I expedición cubano-española a la Isla de la Juventud y Archipiélago de las Canarias. III Familias Dorvilleidae, Arabellidae, Lumbrineridae y Eunicidae. Revista de Investigaciones marinas, 9, 3-13.

Spalding, M. D., Fox, H. E., Allen, G. R., Davidson, N., Ferdaña, Z. A., Finlayson, M., ... Robertson, J. (2007). Marine ecoregions of the world: A bioregionalization of coastal and shelf areas. Bioscience, 57(7), 573-583.

Suárez, A. M., \& Fraga, R. (1978). Poliquetos bentósicos Cubanos 1: Lista de poliquetos errantes. Investigaciones Marinas (Havana), 33, 1-60.

Treadwell, A. L. (1921). Leodicidae of the West Indian Region. Publications of the Carnegie Institution of Washington, 15, 1-31.

Treadwell, A. L. (1931). New species of polychaetous annelids from California, Mexico, Porto Rico, and Jamaica. American Museum Novitates, 482, 1-7.

Tribollet A., Decherf, G., Hutchings, P., \& Peyrot-Clausade, M. (2002). Large-scale spatial variability in bioerosion of experimental coral substrates on the Great Barrier Reef (Australia): importance of microborers. Coral Reefs, 21, 424-432.

Uebelacker, J. M. (1984). Chapter 41. Lumbrineridae; Chapter 42. Arabellidae. In J. M. Uebelacker \& P. G. Johnson (Eds.). Taxonomic Guide to the Polychaetes of the Northern Gulf of Mexico. Final Report to the Minerals Management Service, contract 14-12-00129091 (pp. 41.1-41.5; 42.1-42.29). Mobile, Alabama, USA: Barry A. Vittor and Associates. Inc.

Wolf, P. S. (1984). Chapter 44. Dorvilleidae. In J. M. Uebelacker \& P. G. Johnson (Eds.). Taxonomic Guide to the Polychaetes of the Northern Gulf of Mexico. Final Report to the Minerals Management Service, contract 14-12-001-29091 (pp. 44.1-44.37). Mobile, Alabama, USA: Barry A. Vittor and Associates. Inc.

Wolf, P. S. (1986). Three new species of Dorvilleidae (Annelida: Polychaeta) from Puerto Rico and Florida and a new genus for dorvilleids from Scandinavia and North America. Proceedings of the Biological Society of Washington, 99, 627-638.

Yáñez-Rivera, B. (2009). 7. Amphinomidae Savigny in Lamarck, 1818. In J. A. De León-González, J. R. Bastida-Zavala, L. F. Carrera-Parra, M. E. GarzaGarcía, A. Peña-Rivera, S. I. Salazar-Vallejo \& V. Solís-Weiss (Eds.). Poliquetos (Annelida: Polychaeta) de México y América Tropical (pp. 77-87). México: Universidad Autónoma de Nuevo León.

Yáñez-Rivera, B., \& Brown, J. (2015). Fireworms (Amphinomidae: Annelida) from Ascension and Saitn Helena Island, Central South Atlantic Ocean. Marine Biodiversity Records, 8, e149. 